A HISTORY OF CONSERVATIVE POLITICS, 1900-1996 


\section{British Studies Series}

General Editor JEREMY BLACK

Published

John Charmley A History of Conservative Politics, 1900-1996

David Childs Britain since 1939

David Eastwood Government and Community in the English Provinces, 1700-1870

Brian Hill The Early Parties and Politics in Britain, 1688-1832

Kevin Jefferys Retreat from New Jerusalem: British Politics, 1951-64

T. A. Jenkins The Liberal Ascendancy, 1830-1886

David Loades Power in Tudor England

Murray G. H. Pittock Inventing and Resisting Britain: Cultural Identities in Britain and Ireland, 1685-1789

Andrew Thorpe A History of the British Labour Party

Forthcoming

D. G. Boyce Britain and Decolonisation

Glenn Burgess British Political Thought from Reformation to Revolution

J. B. Christoph The Twentieth-Century British State

Gary De Krey Restoration and Revolution in Britain

W. H. Fraser The Rise and Fall of British Trade Unionism

Jeremy Gregory The Long Reformation: Religion and Society in England c.1530-1870

Katrina Honeyman Women and Industrialization

Jon Lawrence Britain and the First World War

F. J. Levy Politics and Culture in Tudor England

Diarmaid MacGulloch The Reformation in Britain, 1480-1680

Allan Macinnes The British Revolution

G. I. T. Machin The Rise of British Democracy

Thomas Mayer Britain, 1450-1603

Michael Mendle The English Civil War and Political Thought

Alexander Murdoch British History, 1660-1832

W. Rubinstein History of Britain in the Twentieth Century

Howard Temperley Britain and America

\section{British Studies Series}

Series Standing Order

ISBN 978-0-333-71691-5 hardcover

ISBN 978-0-333-69332-2 paperback

(outside North America only)

You can receive future titles in this series as they are published by placing a standing order. Please contact your bookseller or, in case of difficulty, write to us at the address below with your name and address, the title of the series and the ISBN quoted above.

Customer Services Department, Macmillan Distribution Ltd

Houndmills, Basingstoke, Hampshire RG21 6XS, England 


\title{
A HISTORY OF CONSERVATIVE POLITICS, 1900-1996
}

\author{
John Charmley \\ Reader in History at the \\ University of East Anglia
}

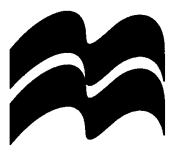


(C) John Charmley 1996, 1998

All rights reserved. No reproduction, copy or transmission of this publication may be made without written permission.

No paragraph of this publication may be reproduced, copied or transmitted save with written permission or in accordance with the provisions of the Copyright, Designs and Patents Act 1988, or under the terms of any licence permitting limited copying issued by the Copyright Licensing Agency, 90 Tottenham Court Road, London W1P 9HE.

Any person who does any unauthorized act in relation to this publication may be liable to criminal prosecution and civil claims for damages.

The author has asserted his right to be identified as the author of this work in accordance with the Copyright, Designs and Patents Act 1988.

\section{Published by}

\section{MACMILLAN PRESS LTD}

Houndmills, Basingstoke, Hampshire RG21 6XS and London Companies and representatives throughout the world

Published in hardcover 1996

Reprinted 1996

Published in paperback 1998

ISBN 978-0-333-72283-1 DOI 10.1007/978-1-349-14691-8

A catalogue record for this book is available from the British Library.

$\begin{array}{cccccccccc}10 & 9 & 8 & 7 & 6 & 5 & 4 & 3 & 2 & 1 \\ 07 & 06 & 05 & 04 & 03 & 02 & 01 & 00 & 99 & 98\end{array}$

Copy-edited and typeset by Povey-Edmondson Tavistock and Rochdale, England

Published in the United States of America 1996 by

ST. MARTIN'S PRESS, INC., Scholarly and Reference Division 175 Fifth Avenue, New York, N.Y. 10010

ISBN 978-0-312-16126-2 cloth 


\section{Contents}

LIST OF PLATES vii

ACKNOWLEDGEMENTS viii

ONE THE CONSERVATIVE TRADITION 1

Two BALFOURIAN DOG DAYS 21

THREE OVER THE TOP WITH BONAR LAW 45

Four SCALPED BY BALDWIN 63

FIVE CHAMBERLAIN \& CO. 85

SIX CHURCHILL'S CONSENSUS 105

SEVEN THE NEW MODEL TORY PARTY? 123

EIght A CONSERVATIVE CONSENSUS? 141

Nine DECLINE AND FALL 163

TEN SELSDON MAN AND

GRANTHAM WOMAN 181

ELEVEN THE IRON LADY 201

Twelve HIGH TIDE AND AFTER 219

EPILOGUE AFTER THE BALL WAS OVER 241 
APPENDIX 257

NOTES AND REFERENCES 261

BIBLIOGRAPHY 275

INDEX 281 


\section{List of Plates}

1. The 'new' Conservatism confronts the embodiment of the old order: Churchill is Prince Hal to Salisbury's Falstaff (Punch)

2. Uneasy coexistence: Chamberlain looks to the future, Balfour looks resigned - painting by Sydney Prior Hall (National Portrait Gallery)

3. Smoke a big cigar and talk softly: Bonar Law with one of his main hobbies (Hulton Deutsch)

4. Always playing the game and losing it: Austen Chamberlain in characteristic pose - on the way out (Hulton Deutsch)

5. Constitutional Conservatives: Neville Chamberlain's corvine elegance contrasts with Baldwin's 'farmer Stan' tweeds (Hulton Deutsch)

6. The bull-dog with his second-in-command: Churchill and Eden in symbolically appropriate pose, photographed attending Lloyd George's memorial service (Associated Press)

7. Harold Macmillan in 1963, looking (as well he might) pensive (Camera Press/Alan Clifton)

8. The last toff at No. 10: Sir Alec Douglas-Home (Hulton Picture Company)

9. 'The good, the bad, the ugly and the other one' - but not in that order: $l$. to $r$., Lord Home, Mrs Thatcher, Lord Stockton and Edward Heath (Camera Press)

10. 'All for one - and every man for himself!': Mr Major's team photograph: $l$. to $r$. Kenneth Clarke, Mr M., Chris Patten, Michael (soon to be 'Prezza') Heseltine, Douglas Hurd and the soon-to-be forgotten Chancellor, Norman Lamont (Financial Times) 


\section{Acknowledgements}

I am grateful to Professor Jeremy Black, now of Exeter University, who first asked me to write this book, as well as to my colleague, Professor Geoffrey Searle, who bore up well under what must have struck him as provocative arguments; his efforts improved the text greatly

I am also grateful to Alan Clark and Andrew Roberts for conversations which informed the ideas which went into the book - even if they will not agree with them.

I would also like to thank my students at the University of East Anglia for their unwitting contributions over the last sixteen years.

I am grateful to my wife, Lorraine, for putting up with my preoccupation with this book.

School of History

John Charmley

University of East Anglia

Norwich 